\title{
Solving multi-objective planning model for equipment manufacturing enterprises with dual uncertain demands using NSGA-II algorithm
}

\author{
Liu, Y.F. ${ }^{\mathrm{a}, \mathrm{b},{ }^{*}}$, Zhang, Q.S. ${ }^{\mathrm{a}}$ \\ ${ }^{a}$ School of Management, Shenyang University of Technology, Shenyang, P.R. China \\ ${ }^{\mathrm{b}}$ School of Management, Bohai University, Jinzhou, P.R. China
}

\begin{abstract}
A B S T R A C T
In the paper we have established a multi-objective planning model. This model can solve the dual uncertainty demand problems of number and delivery time when orders are emergent or are modified for equipment manufacturing enterprises. We used scenario analysis methods to deal with our customers' urgent orders and order revisions. A fuzzy interval analysis was used to describe delivery time requirements, and a random interval analysis was used to describe the quantity of customer demand. The multi-objective production planning model proposed in this paper can solve the objectives pursued by the enterprise to meet the maximization of customer demand and minimization of costs. The NSGA-II genetic algorithm is used to solve the model. Finally, the model is solved by example simulation. Through the input of a large amount of data and the analysis of the operating results, it verified the applicability and effectiveness of the model.
\end{abstract}

(C) 2018 PEI, University of Maribor. All rights reserved.

\author{
ARTICLE INFO \\ Keywords: \\ Equipment manufacturing enter- \\ prises; \\ Dual uncertain demand; \\ Optimization; \\ Multi objective model; \\ Genetic algorithm; \\ NSGA-II algorithm \\ *Corresponding author: \\ liuyfmail1979@163.com \\ (Liu, Y.F.) \\ Article history: \\ Received 23 April 2018 \\ Revised 21 May 2018 \\ Accepted 29 May 2018
}

\section{References}

[1] Soysal, M., Bloemhof-Ruwaard, J.M., Haijema, R., van der Vorst, J.G.A.J. (2015). Modeling an inventory routing problem for perishable products with environmental considerations and demand uncertainty, International Journal of Production Economics, Vol. 164, 118-133, doi: 10.1016/i.ijpe.2015.03.008.

[2] Hasany, R.M., Shafahi, Y. (2017). Two-stage stochastic programming for the railroad blocking problem with uncertain demand and supply resources, Computers \& Industrial Engineering, Vol. 106, 275-286, doi: $10.1016 /$ j.cie.2017.02.014.

[3] Ji, Q., Wang, Y., Hu, X. (2016). Optimal production planning for assembly systems with uncertain capacities and random demand, European Journal of Operational Research, Vol. 253, No. 2, 383-391, doi: 10.1016/j.ejor.2016. $\underline{02.021 .}$.

[4] Mateo, J., Pla, L.M., Solsona, F., Pagès, A. (2016). A production planning model considering uncertain demand using two-stage stochastic programming in a fresh vegetable supply chain context, SpringerPlus, Vol. 5, No. 1, 839, doi: 10.1186/s40064-016-2556-z.

[5] Masaru, T., Masahiro, H. (2003). Genetic algorithm for supply planning optimization under uncertain demand, In: Cantú-Paz, E. et al. (eds.), Genetic and Evolutionary Computation - GECCO 2003, Lecture Notes in Computer Science, Vol. 2724, Springer, Berlin, Heidelberg, Germany, 2337-2346, doi: 10.1007/3-540-45110-2 126.

[6] Ciarallo, F.W., Akella, R., Morton, T.E. (1994). A periodic review, production planning model with uncertain capacity and uncertain demand - Optimality of extended myopic policies, Management Science, Vol. 40, No. 3, 320332, doi: $10.1287 / \mathrm{mnsc}$.40.3.320. 
[7] Shi, J., Zhang, G., Sha, J. (2011). Optimal production planning for a multi-product closed loop system with uncertain demand and return, Computers \& Operations Research, Vol. 38, No. 3, 641-650, doi: 10.1016/i.cor.2010. $\underline{08.008 .}$.

[8] Kim, B., Leung, J.M.Y., Park, K., Zhang, G., Lee, S. (2002). Configuring a manufacturing firm's supply network with multiple suppliers, IIE Transactions, Vol. 34, No. 8,663-67, doi: 10.1080/07408170208928903.

[9] Modiano, E.M. (1987). Derived demand and capacity planning under uncertainty, Operations Research, Vol. 35, No. 2, 185-197, doi: 10.1287/opre.35.2.185.

[10] Xu, W., Liu, L., Zhang, Q., Wang, X. (2017). A multi-object decision-making method for location model of manufacturing industry under uncertain environment, Journal of Interdisciplinary Mathematics, Vol. 20, No. 4, 1019-1028, doi: 10.1080/09720502.2017.1358879.

[11] Xu, W., Yu, Y., Zhang, Q. (2018). A multiobjective decision-making method of service element allocation of customer behaviour, Discrete Dynamics in Nature and Society, Vol. 2018, Article ID 3572094, 16 pages, doi: 10.1155/ 2018/3572094.

[12] Tang, M., Gong, D., Liu, S., Zhang, H. (2016), Applying multi-phase particle swarm optimization to solve bulk cargo port scheduling problem, Advances in Production Engineering \& Management, Vol. 11, No. 4, 299-310, doi: 10.14743/apem2016.4.228. 